\title{
Safety Workaround of Registered Nurses in Malaysian Public Hospitals: A Pilot Study
}

\author{
Surekha Rajandiran \\ Faculty of Educational Studies, Universiti Putra Malaysia \\ Serdang 43400, Malaysia \\ Nor Wahiza Abdul Wahat \\ Faculty of Educational Studies, Universiti Putra Malaysia \\ Serdang 43400, Malaysia
}

Anusuiya Subramaniam (Corresponding author)

School of Business and Economics, Universiti Putra Malaysia

Serdang 43400, Malaysia

Received: Oct. 4, $2021 \quad$ Accepted: Nov. 1, $2021 \quad$ Online published: Nov. 8, 2021

doi:10.5296/ijhrs.v11i4S.19168

URL: https://doi.org/10.5296/ijhrs.v11i4S.19168

\begin{abstract}
Safety workarounds stay a crucial concern for employers, significantly within the healthcare industry wherever hospital nurses' safety has deteriorated throughout the COVID-19 pandemic. This pilot study used descriptive and correlational analyses to explore and analyse the reliability of the constructs of communication barriers, work engagement, and burnout on safety workarounds, and also their relationship. This study was conducted with 30 registered nurses in public hospitals in the State of Perak, Malaysia. The results showed that all scales to measure burnout, work engagement, communication barriers, and safety workaround had moderate to excellent feasibility and had sufficient test-retest reliability. The results also indicate that all two independent factors, namely burnout and communication barrier, were shown to be negatively and significantly correlated with safety workaround, whereas work engagement was found to be positively and significantly correlated with safety workaround. This study is anticipated to fill a spot within the literature as a result of there hasn't been a lot of analysis on nurses' safety workarounds within the Malaysian setting. These results may contribute to a stronger understanding of the constructs of communication barriers, work engagement, and burnout and how to deal with safety workaround of registered nurses in
\end{abstract}


Malaysian public hospitals.

Keywords: communication barriers, work engagement, burnout, safety workaround, nurses, Malaysia

\section{Introduction}

After 27 cases were found in Wuhan, China, Chinese experts notified the WHO of the outbreak of Wuhan pneumonia on December 31, 2019. The number of cases rose to 653 on January 24, and 18 deaths were reported. Approximately one-quarter of those contaminated had ended up seriously sick, but most others had milder side effects. Most who kicked the bucket had fundamental wellbeing issues, and numerous were more seasoned than 60 . The current Covid-19 outbreak started after the SARS disaster in mid-November 2002 and lasted until July 2003. It started in Guangdong, China. According to China's report, there are 5,327 possible cases and 349 deaths. After the epidemic spread to Vietnam, Singapore, and the Philippines at the end of February, Thailand in mid-March, and a few days later to the Malaysian trade fair, Southeast Asian countries were on high alert. Malaysians have a mortality rate of $40 \%$ at the end of the flare (Kenanga., 2020). Despite record expenditures, the healthcare industry performed poorly and caused major concerns due to a large number of clinical errors (Graber, 2013).

As we know, the Coronavirus (COVID-19) widespread has spread around the world. This widespread has caused not as it were dead but the intolerable mental weight on hospital workers over the world particularly the mental wellbeing of the medical caretakers and numerous of them have endured from uneasiness related behavior. One of its negative results is the overburden of work completed and a deficiency of resting among the medical attendants. J Lai et al 2020 conducted a later study in Wuhan. China has concluded that medical attendants, frontline health care specialists, and those working in Wuhan, China, detailed higher levels of all estimates of mental wellbeing side effects than other wellbeing care workers. In addition, nurses inside the US hospitality segment experienced intemperate workloads and long working hours, work weight, time limitations, exceedingly strong work conditions, lacking preparation and assurances for his or her wellbeing and security (Ariza-Montes et al., 2017).

Healthcare specialists are 'masters' of workarounds (Morath \& Turnbull,2005). Workarounds are transcendent inside the healthcare community, particularly in frontline care. The nursing calling could be a high-demand profession that requires the person's capacity to manage and oversee beneath strongly physical and passionate elements within the work environment (Ali et al., 2020; Permarupan et al, 2020). As patient liaisons, nurses play an important role in the ability to deal with the organization. Their psychological attitudes and behaviors towards patients have a decisive influence on the patients' realization and perception of welfare quality (Othamn \& Mohd Nasrudin. A, 2012).

Workarounds are often seen as deviations from best practices, putting patients at risk due to poor results (Seaman et al., 2015). Since safety workarounds are performed under pressure to comply with rules or meet other work requirements, they may also have negative consequences, such as treatment errors that may lead to wounds (Halbesleben, 2010) or even 
patients' downfall. When workers see that their pioneers care about safety, they are more likely to raise safety issues and report errors (Halbesleben et al., 2013). Therefore, by focusing on representative participation, it can stimulate, build and develop the current workforce, making them more enjoyable and more likely to provide high-quality care. When the desire of workaround and reality surrounding work change, job burnout begins (Ruotsalainen et al., 2015). Burnout is usually latent and can only be recognized when it becomes severe and is considered a job-specific disorder (Bianchi R et al., 2014; Mohd Rasdi et al., 2021).

Enthusiastic bolster plays a critical part in patients' mental and physical alteration to their malady. When going up against a traumatic occasion, such as cancer, most people have a strong desire to make strides in their self-esteem or to diminish sentiments of individual insufficiency. Undoubtedly, patients distinguish enthusiastic back as the foremost accommodating kind of bolster (Dakof \& Taylor, 1990). Nurses spend the most time with patients of any healthcare provider, and they typically devote themselves to building a competent medical relationship that facilitates treatment and communication between the two parties. Physical, semantic, or psychological barriers to communication might affect the sender, recipient, or communication channel (Lunenburg, 2010). Therefore, the purpose of this pilot study was (1) to assess the reliability of the questionnaire towards measuring the study constructs, which consist of burnout, work engagement, and communication barriers on safety workaround among public hospitals nurses, and (2) to explore the relationship between the constructs. Why is this problem important?

\section{Method}

The study was conducted in an emerging Southeast Asian country in Malaysia. A pilot study involving 30 (Sheatsley, 1983; Sudman, 1983) nurses with informed consent was conducted in six districts in Perak. A pilot study plays an important role as a stepping stone to a broader project in future and to determine the feasibility of using the questionnaire and data collection process (Fraser et al., 2018). Before the self-administered questionnaire, it was approved by the National Medical Research Register (NMRR) and the Medical Research Ethics Committee.

\subsection{Instrument}

The analysis instrumentation was in an exceeding sort of close-ended questions that were tailored from previous studies. The form was composed of 4 sections and consisted of 46 items in total, starting from 'strongly disagree' (1) to 'strongly agree' (5).

Burnout. The 14 items Shirom-Melamed Burnout measure (SMBM; Shirom, 1989) are tailored to judge burnout in workaround using a five-point Likert scale, going from (strongly disagree) 1 to (strongly agree) 5. It's a free resource survey that solely needs correct citation or credit to the author and publisher. It conceptualizes burnout because of the depletion of energetic resources, characteristic between (6 items) physical fatigue for the associate in nursing example "I have no energy for going to work in the morning", (three-item) emotional exhaustion for associate degree example "I feel I'm unable to be sensitive to the wants of co-workers and patients", associate degreed (five-item) cognitive weariness for an example 


\section{$\triangle$ Macrothink}

"My thinking method is slow". A pilot study of the form was administered with a similar population and also Cronbach alpha was 0.886 was obtained.

Work Engagement. The Utrecht Work Engagement Scale (UWES 17) developed by (Schaufeli et al., 2003) is tailored to measure exploitation 5-points Likert scale - sort ranging from 1 (strongly disagree) to 5 (strongly agree) which constituting dimension of vigor, dedication, and absorption. It is a free resource survey that only requires proper citation or credit to the author and publisher. The UWES has a total of 17 statements representing the three domains. Vigor domain contained six statements for example "I can continue working for very long periods at a time". The dedication domain consists of five statements for example "I find the work that I do full of meaning and purpose". The remaining six statements belonged to the absorption domain for example "When I am working, I forget everything else around me". A pilot study of the form was administered with a similar population and therefore the Cronbach alpha was 0.814 was obtained.

Communication Barrier. Self-administered questionnaires by (Maniam et al, 2018), Eleven items lined the most factors associated with nurse-patient communication that square measure the nurse connected factors that hinder communication. items are measured on a five-point Likert scale, going from strongly disagree (1) to strongly agree (5) for the associate in nursing example "Nurses must limit contact to a minimum so that they may devote their time to other tasks". As a result of the form's pilot testing with a comparable population, a Cronbach alpha of 0.748 was attained.

Safety Workaround. The assemble of workarounds will be examined through 5 items from (Halbesleben, J. R. B., Wakefield, D. S., \& Wakefield, B. J. 2008) will tailor to degree the use of the range on a 5-point Likert scale going from strongly disagree (1) to strongly agree (5) for an example "I even have altered my paintings methods due to the fact guidelines or regulations maintain me from doing my activity efficiently". Pilot testing of the questionnaire was completed with a comparable population, yielding a Cronbach alpha of 0.882 .

\subsection{Reliability}

Cronbach's alpha is a degree of the inner consistency or reliability among numerous items, measurements, or rankings to estimate how dependable are the responses of a questionnaire that is evaluated through topics to perceive the stability of the tools (Bujang et al., 2018). The value of Cronbach's alpha stages from 0 to 1 with a better degree indicating the objects are measuring the identical dimension and if the value is low or close to 0 , it suggests all of the objects aren't measuring the identical dimension (Bujang et al., 2018). Prior scholars (Hinton et al, 2004), have recommended 4 cut-off points for reliability, which includes excellent reliability (0.90 and above), high reliability (0.70-0.90), moderate reliability (0.50-0.70), and low reliability ( 0.50 and below). With Cronbach's $\alpha$ of each and overall construct ranging between 0.748 to 0.886 , the reliability of the questionnaire for this study was considered to have high internal consistency and sufficient to an acceptable value for research purposes. Table 1 summarizes the findings

\subsection{Sampling Procedures}

Describe the settings and locations in which the data were collected as well as any 
agreements and payments made to participants, agreements with the institutional review board, ethical standards met, and safety monitoring procedures.

In total,30 participants participated in this pilot study by completing the questionnaires over a period of 3 weeks from end of February to beginning of March 2021. Cluster sampling was utilized. The nurses consist of male and female participants, between the age of 20 to 60 years old, full time staff nurses with at least 3 months of professional nursing experience. The nurses were chosen regards to six issues relate to the respondents ' gender, age, ethical background, marital status, department attached to at the moment and years of working experience as a nurse'. The researcher distributed the questionnaire among the nurses with the help of the person in charge in the Human Resource Unit, as well the person who is in charge of the nurses in each department: Critical Care Department, Emergency Department, Maternity Department, Dialysis Department, Pediatrics Department, Surgical Department, Orthopedic Department, Obstetrics and Gynecology Department, Medical Department, Oncology Department, Cardiology Department and Neurology Department. Head nurses and together with nurses who are part-time, volunteer, or nurses in training will not be included in this study. The unit of analysis in this study is the individual nurses and not the public hospitals. According to Sekaran (2019), if the unit of analysis is an individual, the researcher is looking at the data obtained from every person and treating each person's answer as an individual data source.

Table 1. Reliability Test Result

\begin{tabular}{|c|c|c|}
\hline Construct & $\begin{array}{c}\text { Number of } \\
\text { Items }\end{array}$ & Cronbach's Alpha \\
\hline Burnout & 13 & 0.886 \\
\hline Work Engagement & 17 & 0.814 \\
\hline $\begin{array}{c}\text { Communication } \\
\text { Barrier }\end{array}$ & 11 & 0.748 \\
\hline Safety Workaround & 4 & 0.815 \\
\hline
\end{tabular}

Burnout reached the highest reliability value (Cronbach's $\alpha=0.886$ ), followed by safety workaround (Cronbach's $\alpha=0.815$ ), work engagement (Cronbach's $\alpha=0.814$ ), and communication barrier (Cronbach's $\alpha=0.748$ ). All the Cronbach's alpha values have been desirable and had an excessive degree of inner consistency that allowed it to continue for real study, as Cronbach's $\alpha$ desirable cost ought to be above 0.70 (Bujang et al., 2018). No items have been required to be amended or dropped.

\section{Data Analysis}

The statistics have been analyzed with the usage of Statistical Package for Social Sciences (SPSS) version 27. Descriptive evaluation became executed for socio-demographic profile, including gender, age, ethnicity, marital status, hospital attached, department, and duration of working experience. For the reliability test, the corrected item-total correlation the usage of Cronbach alpha coefficient was carried out to make certain inner consistency in every and standard construct. 


\subsection{Ethics Statement}

Approval was obtained from the National Medical Research Register (NMRR) and the Medical Research Ethics Committee before self-administering the questionnaire. This research was conducted under the approval of the National Medical Research Register (NMRR): NMRR20195856255 (IIR). The consent of all participants has been obtained and confidentiality is guaranteed.

\section{Results}

A sum of 30 nurses participated in the study. Table 2 summarizes the socio-demographic profile, based on the pilot study.

Table 2. Socio-Demographic profile

\begin{tabular}{|c|c|c|}
\hline Variables & Frequency & Percentage $(\%)$ \\
\hline \multicolumn{3}{|l|}{ Gender } \\
\hline Female & 27 & 90 \\
\hline Male & 3 & 10 \\
\hline \multicolumn{3}{|l|}{ Age } \\
\hline $20-30$ & 2 & 6.7 \\
\hline $31-40$ & 12 & 40 \\
\hline $41-50$ & 12 & 40 \\
\hline $51-60$ & 4 & 13.3 \\
\hline \multicolumn{3}{|l|}{ Ethnic } \\
\hline Malay & 29 & 96.7 \\
\hline Chinese & 0 & \\
\hline Indian & 0 & \\
\hline Others & 1 & 3.3 \\
\hline \multicolumn{3}{|l|}{ Marital Status: } \\
\hline Single & 2 & 6.7 \\
\hline Married & 28 & 93.3 \\
\hline Others & 0 & \\
\hline \multicolumn{3}{|l|}{ Department } \\
\hline Critical Care & 0 & \\
\hline Emergency & 1 & 3.3 \\
\hline Maternity & 1 & 3.3 \\
\hline Dialysis & 0 & \\
\hline Pediatric & 0 & \\
\hline Surgical & 2 & 6.7 \\
\hline Orthopedic Department & 0 & \\
\hline $\begin{array}{l}\text { Obstetrics and Gynecology } \\
\text { Department }\end{array}$ & 11 & 36.7 \\
\hline Medical Department & 13 & 43.3 \\
\hline Oncology Department & 0 & \\
\hline Cardiology Department & 2 & 6.7 \\
\hline Neurology Department & 0 & \\
\hline \multicolumn{3}{|l|}{ Duration of Working Experience } \\
\hline Less than 5 years & 1 & 3.3 \\
\hline 5 to 10 years & 8 & 26.7 \\
\hline More than 10 years & 21 & 70.0 \\
\hline
\end{tabular}




\section{Ml Macrothink}

The majority (90\%) of the registered nurses was female and $10 \%$ was male. As for their age, most of them were 31-40 and 41-50 years old and equally above (40\%), followed by $51-60$ years old (13.3\%).6.7\% were within 20 to 30 years old. With regards to respondents' age, most of them were Malay (96.7\%). Most of the respondents were married (93.3\%) and (6.7\%) of them were single. With regards to the department, the majority (43.3\%) of the respondent were attached to the medical department, followed by $(36.7 \%)$ of the respondents were attached to the obstetrics and gynecology department, $3.3 \%$ of them attached to the emergency and maternity and finally, $6.7 \%$ of them attached to the surgical and cardiology department. In terms of working years, $3.3 \%$ of respondents have less than five years of professional experience, $26.7 \%$ of respondents have five to ten years of professional experience, and $70 \%$ of respondents have more than ten years of professional experience.

Table 3. Frequency and Percentage for Each Item

\begin{tabular}{|c|c|c|c|c|c|c|}
\hline No. & Items & $\begin{array}{l}\text { Strongly } \\
\text { Disagree }\end{array}$ & Disagree & Neutral & Agree & $\begin{array}{l}\text { Strongly } \\
\text { Agree }\end{array}$ \\
\hline 1 & $\begin{array}{l}\text { I'm unable to be sympathetic to my } \\
\text { coworkers' and patients' requirements. }\end{array}$ & $27(90 \%)$ & $1(3.3 \%)$ & & $2(6.7 \%)$ & \\
\hline 2 & $\begin{array}{l}\text { I'm not capable of emotionally } \\
\text { investing in my coworkers or patients. }\end{array}$ & $29(96.7 \%)$ & $1(3.3 \%)$ & & & \\
\hline 3 & $\begin{array}{l}\text { I'm not good at empathizing with } \\
\text { coworkers or patients. }\end{array}$ & $25(83.3 \%)$ & $3(10 \%)$ & $2(6.7 \%)$ & & \\
\hline 4 & exhausted & $12(40 \%)$ & $4(13.3 \%)$ & $12(40 \%)$ & $2(6.7 \%)$ & \\
\hline 5 & $\begin{array}{l}\text { I'm too tired to go to work in the } \\
\text { morning. }\end{array}$ & $25(83.3 \%)$ & $5(16.7 \%)$ & & & \\
\hline 6 & drained physically & $23(76.7 \%)$ & $7(23.3 \%)$ & & & \\
\hline 7 & unhappy & $23(76.7 \%)$ & $5(16.7 \%)$ & $2(6.7 \%)$ & & \\
\hline 8 & as though my "batteries" have died & $24(80 \%)$ & $6(20 \%)$ & & & \\
\hline 9 & extinguished & $17(56.7 \%)$ & $13(43.3 \%)$ & & & \\
\hline 10 & My thought process takes a long time. & $23(73.3 \%)$ & $7(23.3 \%)$ & & & \\
\hline 11 & $\begin{array}{l}\text { I have trouble concentrating. I have } \\
\text { the impression that I am not thinking } \\
\text { clearly. }\end{array}$ & $22(73.3 \%)$ & $8(26.7 \%)$ & & & \\
\hline 12 & I feel I'm not focused in my thinking & $24(80 \%)$ & $6(20 \%)$ & & & \\
\hline 13 & $\begin{array}{l}\text { I have a hard time thinking about } \\
\text { complicated issues. }\end{array}$ & $23(76.7 \%)$ & $7(23.3 \%)$ & & & \\
\hline 14 & $\begin{array}{l}\text { I'm bursting at the seams with } \\
\text { enthusiasm at work. }\end{array}$ & & $19(63.3 \%)$ & $5(16.7 \%)$ & $4(13.3 \%)$ & $2(6.7 \%)$ \\
\hline 15 & I feel powerful and energized at work. & & & $9(30 \%)$ & $19(63.3 \%)$ & $2(6.7 \%)$ \\
\hline 16 & $\begin{array}{l}\text { I feel like going to work when I get } \\
\text { up in the morning. }\end{array}$ & & & $13(43.3 \%)$ & $13(43.3 \%)$ & $4(13.3 \%)$ \\
\hline 17 & $\begin{array}{l}\text { I can work for extended amounts of } \\
\text { time. }\end{array}$ & & $13(43.3 \%)$ & $13(43.3 \%)$ & $3(10 \%)$ & $1(3.3 \%)$ \\
\hline 18 & Mentally, I am quite robust at work. & & $3(10 \%)$ & $4(13.3 \%)$ & $22(73.3 \%)$ & $1(3.3 \%)$ \\
\hline 19 & $\begin{array}{l}\text { Even when things aren't going well at } \\
\text { work, I never give up. }\end{array}$ & & $1(3.3 \%)$ & $2(6.7 \%)$ & $26(86.7 \%)$ & $1(3.3 \%)$ \\
\hline 20 & $\begin{array}{l}\text { I find that the work I perform has a lot } \\
\text { of significance and purpose. }\end{array}$ & & & $3(10 \%)$ & $14(46.7 \%)$ & $13(43.3 \%)$ \\
\hline 21 & I am ecstatic with my work. & & & $4(13.3 \%)$ & $25(83.3 \%)$ & $1(3.3 \%)$ \\
\hline 22 & My job motivates me. & & & $1(3.3 \%)$ & $26(86.7 \%)$ & $3(10 \%)$ \\
\hline 23 & I am pleased with the work that I & & & $1(3.3 \%)$ & $16(53.3 \%)$ & $13(43.3 \%)$ \\
\hline
\end{tabular}


24 My work is hard for me.

25 When I'm working, time flies.

26 When I'm working, I lose track of everything else.

27 When I'm working hard, I'm happiest.

28 I'm completely absorbed in my task.

29 When I'm working, I get carried away.

30 It's tough for me to separate myself from my work.

31 Nurses must limit communication to a minimum so that they can focus on other tasks.

32 Effective communication isn't essential for providing effective patient-centered care.

33 I have so much work to accomplish that I can't even spare a few minutes to chat with my patients.

34 The patient's medical state influences a nurse's readiness to interact and communicate with a patient.

35 There is no time to chat with patients since routine work is regularly scheduled and organized.

36 Because there are so many patients to see, nurses must speak quickly when speaking with them.

37 In nursing practice, there are no substantial gaps or difficulties in nurse-patient communication.

38 I don't have a lot of time throughout the shift to communicate with patients.

39 Because there is no way to clarify medical jargon, nurses utilize them while speaking with patients.

40 As a nurse, I'm only interested in conversing with patients who understand my accent.

41 As a nurse, I prefer patients who are members of my ethnic community.

42 To get work done, I ignore the organization's safety regulations.

43 When teaching restricts their efficacy, many people avoid it.

44 I don't always respect the anticipated manner of functioning since it appears to be ineffective.

45 Even if it makes my task take longer, I rarely follow safety procedures.

46 Because a safety precaution slows me down, I change my work procedures to avoid it.

\begin{tabular}{|c|c|c|c|c|}
\hline \multirow[b]{3}{*}{$1(3.3 \%)$} & & $1(3.3 \%)$ & $14(46.7 \%)$ & $15(50 \%)$ \\
\hline & $1(3.3 \%)$ & $12(40 \%)$ & $14(46.7 \%)$ & $3(10 \%)$ \\
\hline & $9(30 \%)$ & $14(46.7 \%)$ & $5(16.7 \%)$ & $1(3.3 \%)$ \\
\hline \multirow{4}{*}{$2(6.7 \%)$} & $1(3.3 \%)$ & $12(40.0 \%)$ & $16(53.3 \%)$ & $1(3.3 \%)$ \\
\hline & $11(36.7 \%)$ & $2(6.7 \%)$ & $14(46.7 \%)$ & $1(3.3 \%)$ \\
\hline & $12(40 \%)$ & $3(10 \%)$ & $15(50 \%)$ & \\
\hline & $11(36.7 \%)$ & $5(16.7 \%)$ & $14(46.7 \%)$ & \\
\hline $9(30 \%)$ & $1(3.3 \%)$ & $16(53.3 \%)$ & $4(13.3 \%)$ & \\
\hline $28(93.3 \%)$ & $1(3.3 \%)$ & $1(3.3 \%)$ & & \\
\hline $3(10 \%)$ & $21(70 \%)$ & $3(10 \%)$ & $1(3.3 \%)$ & $2(6.7 \%)$ \\
\hline $1(3.3 \%)$ & $3(10 \%)$ & $9(30 \%)$ & $15(50 \%)$ & $2(6.7 \%)$ \\
\hline $3(10 \%)$ & $25(83.3 \%)$ & $2(6.7 \%)$ & & \\
\hline \multirow[t]{2}{*}{$13(43.3 \%)$} & $5(16.7 \%)$ & $11(36.7 \%)$ & $1(3.3 \%)$ & \\
\hline & $4(13.3 \%)$ & $22(73.3 \%)$ & $3(10 \%)$ & $1(3.3 \%)$ \\
\hline $5(16.7 \%)$ & $24(80 \%)$ & $1(3.3 \%)$ & & \\
\hline $4(13.3 \%)$ & $14(46.7 \%)$ & $10(33.3 \%)$ & $2(6.7 \%)$ & \\
\hline $25(8.3 \%)$ & $5(16.7 \%)$ & & & \\
\hline $27(90 \%)$ & $3(10 \%)$ & & & \\
\hline $13(43.3 \%)$ & $13(43.3 \%)$ & $4(13.3 \%)$ & & \\
\hline $2(6.7 \%)$ & $11(36.7 \%)$ & $16(53.3 \%)$ & $1(3.3 \%)$ & \\
\hline $12(40 \%)$ & $12(40 \%)$ & $2(6.7 \%)$ & $4(13.3 \%)$ & \\
\hline $11(36.7 \%)$ & $1(3.3 \%)$ & $14(46.7 \%)$ & $4(13.3 \%)$ & \\
\hline $13(43.3 \%)$ & $15(50 \%)$ & $2(6.7 \%)$ & & \\
\hline
\end{tabular}


Table 3 reveals the findings associated with the frequency and percentage of 46 items which were distributed to the nurses, indicating that respondents have a lower level of agreement towards burnout, moderate level of agreement towards work engagement, moderate level of agreement towards communication barrier, and a higher level of agreement towards safety workaround. As a result, when the burnout is reduced, the work engagement improves and so does the safety workaround, and when the communication barrier increases, it reduces safety workaround or vice versa.

\subsection{Pearson Correlation Analysis}

The degree of connection or relationship between continuous data was measured and interpreted using correlation analysis. Pearson's product-moment correlation coefficient (r) was employed to represent the strength and direction of the association (Cohen, 1988). Furthermore, there are guidelines for assessing Pearson's product-moment correlation coefficient (r) values, whereby 0.1-0.29, 0.3-0.49, and 0.5-1.00 are considered weak, moderate, and strong relationships (Cohen,1988).

Table 4. Correlation Analysis Result

\begin{tabular}{|c|c|c|c|c|c|}
\hline & & BOTOTAL & WETOTAL & CBTOTAL & SWTOTAL \\
\hline \multirow{3}{*}{$\mathrm{BO}$} & Pearson Correlation & 1 & $-.241^{* *}$ & $.563^{* *}$ & $-.469^{* *}$ \\
\hline & Sig. (2-tailed) & & .000 & .000 & .000 \\
\hline & $\mathrm{N}$ & 559 & 559 & 559 & 559 \\
\hline \multirow{3}{*}{ WE } & Pearson Correlation & $-.241^{* *}$ & 1 & $-.199^{* *}$ & $.237^{* *}$ \\
\hline & Sig. (2-tailed) & .000 & & .000 & .000 \\
\hline & $\mathrm{N}$ & 559 & 559 & 559 & 559 \\
\hline \multirow{3}{*}{$\mathrm{CB}$} & Pearson Correlation & $.563^{* *}$ & $-.199^{* *}$ & 1 & $-.585^{* *}$ \\
\hline & Sig. (2-tailed) & .000 & .000 & & .000 \\
\hline & $\mathrm{N}$ & 559 & 559 & 559 & 559 \\
\hline \multirow{3}{*}{ SW } & Pearson Correlation & $-.469^{* * *}$ & $.237^{* *}$ & $-.585^{* *}$ & 1 \\
\hline & Sig. (2-tailed) & .000 & .000 & .000 & \\
\hline & $\mathrm{N}$ & 559 & 559 & 559 & 559 \\
\hline
\end{tabular}

**. Correlation is significant at the 0.01 level (2-tailed).

** Burnout (BO), Work Engagement (WE), Communication Barrier (CB), Safety Workaround (SW)

As shown in Table 4, the results show that all three independent variables: burnout and communication barrier were negatively and significantly correlated with safety workaround (p-value < 0.01), and work engagement was positively and significantly correlated with safety workaround ( $\mathrm{p}$-value $<0.01$ ). In terms of the strength of association with a tendency for safety workaround, burnout $(\mathrm{r}=-0.469)$ indicates a negative and moderate relationship, communication barrier $(\mathrm{r}=-0.585)$ indicates a strong and negative relationship and work engagement $(r=0.237)$ indicates a weak and positive relationship. Based on the table by Cohen (1988), all predictors qualify for string correlation with safety workaround in this 
study among registered nurses in Malaysian public hospitals.

\section{Discussion}

The purpose of this pilot study was to determine the reliability of the questionnaire used in this study. The reliability of the questionnaire for this study was considered to have internal consistency and sufficient to an acceptable value for the research purpose. Findings associated with the frequency indicate that respondents/nurses have a moderate level of agreement towards communication barrier, moderate level of agreement towards work engagement, lower level of agreement towards burnout, and a higher level of agreement towards safety workaround.

According to Rao et al. (2012), employee engagement is a critical issue for 21st-century professionals, particularly nurses in the healthcare industry. Employee engagement, according to Saks (2006), is related to employees' tendencies, states of mind, and behavioral intention. According to the UK government-commissioned report "Engaging for Success" (MacLeod and Clarke, 2009), good-quality communication improves engagement in public, private, and non-profit organizations. Clear, precise and timely communication of information also prevents the occurrence of organizational problems. Poor communication is cited as a barrier to engagement and a cause of separation. Successful communication is an important aspect of long-term care because it improves the nurse-patient relationship and has a significant impact on the patient's perceptions of health care quality and treatment outcomes ( $\mathrm{Li}$, Ang, \& Hegney, 2012). According to Luthans and Peterson (2001), a worker's level of work engagement can influence his or her ability to engage a group or bunch. As per Bambacas and Patrickson (2008), it is necessary to be able to deliver clear and consistent messages. Truss et al., (2006), on the other hand, conclude that "the capacity to consult, allude, and inclusion are fundamental administrative aptitudes that require more improvement for a significant number of managers." They also claim that $46 \%$ of people do not feel interested or included in their jobs. This could be because, as Waymer and Ni (2009) point out, employees can sometimes find themselves "battling against the dominant talk of the organization". Salem (2008) identifies poor interpersonal communication barrier abilities and strife avoidance as key impediments in the developing communication practice that supports employee engagement setting of altering communication. When employees in the hospitality industry face an overwhelming workload and fewer assets (e.g social support), they tend to lose valuable assets (energy, time, and emotions), and their involvement stretches (Mansour \& Commeiras, 2015).

Concurring to (Serranheira et al, 2016), a hospital has features that affect essentially the everyday lives of its laborers, since it could utilize different procedures and nonstop and shift work to clarify the complex viewpoints of the organization distributed within the progressive structure. Hence, Mera (2009) stated that the physical and psychological viewpoints of hospital laborers are included, especially by nursing experts. Works in a setting of task accumulation, work overburden, shift work, managing much with the enduring of others and death, develops a passionate bond with patients and they're enduring and is always exposed to contamination risk. Higher burnout levels are also associated with unfavorable outcomes, 
comprehension disappointment, and increased complaints from patients and relatives. This may be clarified by emotional fatigue and depersonalization, which can cause fatigue and critical feelings among healthcare workers' wellbeing and distance themselves from the needs of patients and make them feel cold, subsequently influencing the quality of care. Workload, according to Profit J. et al. (2014), is a determining factor for professional fatigue. High hourly loads, in particular, had a significant negative impact on patient safety for health professionals with high burnout rates (Bogaert et. al., 2014). Garcia (2019) concluded that high levels of burnout are more common among nurses and are associated with external factors such as a heavy workload, long commutes, and ineffective interpersonal relationships. Organized workflows that foster autonomy in health professionals influence good patient safety practices and have discovered a $66.4 \%$ probability of superiority relationship between the development of burnout and patient safety actions using meta-analysis. Therefore, there is a relation between high levels of burnout and poor patient safety.

As a result, for this study when the communication barrier improves, so does work engagement and so does safety workaround, and when burnout reduces, it improves the safety workaround or vice versa. The study discovered that burnout, work engagement, and communication barriers experienced by these professionals lead to increased vulnerability and the development of unsafe care and that factors such as a lack of organizational support can help to prevent these failures. As a result, the goals of this pilot study were to (1) assess the questionnaire's reliability in measuring the study constructs, which included burnout, work engagement, and communication barriers on safety workaround among public hospital nurses, and (2) explore the relationship between the constructs.

\section{Conclusion}

As stated in the introduction to this study, very few studies on this relationship have been conducted in hospital organizations in recent years. Therefore, it is noteworthy that this study was able to find such a strong connection between burnout, work engagement, and communication barriers on safety workaround. The results of this study show that the closed-ended questionnaire distributed to nurses is reliable, with an overall Cronbach alpha of greater than 0.07, (Bujang et al., 2018). The reliability of the questionnaire for this study was considered to have high internal consistency and sufficient to an acceptable value for research purposes, with Cronbach's of each and overall construct ranging between 0.748 and 0.886 . The questionnaire is reliable and acceptable for determining the influence of burnout, work engagement, and communication barriers on safety workaround among nurses in public hospitals in Malaysia.

The frequency analysis for each construct shows that Malaysian nurses are aware of safety workarounds. Frequency and percentage reveal the findings associated with the 46 items which were distributed to the nurses, indicating that respondents have a lower level of agreement towards burnout, moderate level of agreement towards work engagement, moderate level of agreement towards communication barrier, and a higher level of agreement towards safety workaround. As a result, when the burnout is reduced, the work engagement improves and so does the safety workaround, and when the communication barrier increases, 
it reduces safety workaround or vice versa. The influence of burnout on work engagement, as well as the influence of communication barriers on the relationship between work engagement and safety workaround.

Correlation analysis was used to assess and analyze the strength of the link or relationship between two continuous variables. Pearson's product-moment correlation coefficient (r) was employed to show the association's strength and direction. (Cohen, 1988). The findings revealed that all three independent variables, i.e.: burnout and communication barrier were negatively and significantly correlated with safety workaround (p-value $<0.01$ ), and work engagement was positively and significantly correlated with safety workaround (p-value < 0.01). Based on the outcome all predictors qualify for string correlation with safety workaround in this study among registered nurses in Malaysian public hospitals.

Workarounds make it possible to give patient care, but they may have unintended consequences. In some situations, such improvisations may be important for successful development of quality treatment, but they are harmful in others. Workarounds are individual strategies people use to deal with difficult circumstances. They are also strategies that are mutually supportive. As an outcome of this burnout has been shown to have a significant impact on safety workaround among nurses in Malaysian public hospitals.

\section{Conflict of interests}

The authors state that they do not have any conflicts of interest.

Funding: This study received no outside funding.

\section{Acknowledgment}

The authors would like to thank Malaysia's Ministry of Health for granting permission to conduct the study. The authors also thank the administrators of the public hospitals as well as the nurses who took part in the study.

\section{Reference}

Ali, N. H. M., Hassan, S. A., Jailani, O., Zaremohzzabieh, Z., \& Lee, Z. J. (2020). The Impact of Supervisory Styles on Satisfaction of Undergraduate Counselling Interns in Malaysia. Asian Journal of University Education, 16(3), 138-147.

Ariza-Montes, A., Arjona-Fuentes, J. M., Law, R., \& Han, H. (2017). Incidence of workplace bullying among hospitality employees. International Journal of Contemporary Hospitality Management, 29(4), 1116-1132. https://doi.org/10.1108/ijchm-09-2015-0471

Bambacas, M., \& Patrickson, M. (2008). Interpersonal communication skills that enhance organisational commitment. Journal of Communication Management, 12(1), 51-72. https://doi.org/10.1108/13632540810854235

Barner-Barry, C. (1990). Cohen, J. (1988) statistical power analysis for the social sciences, 2nd ed. Lawrence Erlbaum Associates, Publishers. Politics and the Life Sciences, 9(1), 156. https://doi.org/10.1017/s0730938400010418 


\section{Macrothink}

International Journal of Human Resource Studies

ISSN 2162-3058

2021, Vol. 11, No. 4S

Bianchi, R., Truchot, D., Laurent, E., Brisson, R., \& Schonfeld, I. S. (2014). Is burnout solely job-related? A critical comment. Scandinavian Journal of Psychology, 55(4), 357-361. https://doi.org/10.1111/sjop.12119

Bujang, M. A., Omar, E. D., \& Baharum, N. A. (2018). A Review on Sample Size Determination for Cronbach's Alpha Test: A Simple Guide for Researchers. Malaysian Journal of Medical Sciences, 25(6), 85-99. https://doi.org/10.21315/mjms2018.25.6.9

Chartered Institute of Personnel and Development. (2006). Working life: employee attitudes and engagement 2006 - LSE Research Online. Truss, Katie, Soane, Emma, Edwards, Christine Yvonne L, Wisdom, Karen, Croll, Andrew and Burnett, Jamie. http://eprints.lse.ac.uk/25807/

C. L. Cooper and I. T. Robertson (eds.): International Review of Industrial and Organizational $\begin{array}{llllll}\text { Psychology } 1988 . & \text { (1989). Organization } & \text { Studies, } & 10(3), & 449 .\end{array}$ https://doi.org/10.1177/017084068901000317

Coronavirus: Impact on Malaysia's Economy May impact VMY2020, the services sector, and fiscal balance sheet - Google zoeken. (2020). Kenanga. https://www.google.com/search?q=Coronavirus\%3A+Impact+on+Malaysia\%E2\%80\%99s+E conomy+May+impact+VMY2020\%2C+the+services+sector\%2C+and+fiscal+balance+sheet $\& \mathrm{rlz}=1 \mathrm{C} 1 \mathrm{GCEA}$ enMY888MY889\&oq=Coronavirus\%3A+Impact+on+Malaysia\%E2\%80\% 99s+Economy+May+impact+VMY2020\%2C+the+services+sector\%2C+and+fiscal+balance + sheet\&aqs $=$ chrome.69i57j69i58.3196j0j7\&sourceid $=$ chrome $\& \mathrm{ie}=\mathrm{UTF}-8$

Dakof, G. A., \& Taylor, S. E. (1990). Victims' perceptions of social support: What is helpful from whom? Journal of Personality and Social Psychology, 58(1), 80-89. https://doi.org/10.1037/0022-3514.58.1.80

Fred C. LunenburgSam Houston State University. (2019, January 26). Communication: The Process, Barriers, And Improving.../communication-the-process-barriers-and-improving.pdf /. PDF4PRO.

https://pdf4pro.com/view/communication-the-process-barriers-and-improving-56e $902 . \mathrm{html}$

Frade Mera, M., Vinagre Gaspar, R., Zaragoza García, I., Viñas Sánchez, S., Antúnez Melero, E., ÁLvarez González, S., \& Malpartida Martín, P. (2009). Síndrome de burnout en distintas Unidades de Cuidados Intensivos. Enfermería Intensiva, 20(4), 131-140. https://doi.org/10.1016/s1130-2399(09)73221-3

Fraser, J., Fahlman, D. W., Arscott, J., \& Guillot, I. (2018). Pilot Testing for Feasibility in a Study of Student Retention and Attrition in Online Undergraduate Programs. The International Review of Research in Open and Distributed Learning, 19(1). https://doi.org/10.19173/irrodl.v19i1.3326

Garcia, C., Abreu, L., Ramos, J., Castro, C., Smiderle, F., Santos, J., \& Bezerra, I. (2019). Influence of Burnout on Patient Safety: Systematic Review and Meta-Analysis. Medicina, 55(9), 553. https://doi.org/10.3390/medicina55090553 
Graber, M. L. (2013). The incidence of diagnostic error in medicine. BMJ Quality \& Safety, 22(Suppl 2), ii21-ii27. https://doi.org/10.1136/bmjqs-2012-001615

Halbesleben, J. R. B. (2010). The role of exhaustion and workarounds in predicting occupational injuries: A cross-lagged panel study of health care professionals. Journal of Occupational Health Psychology, 15(1), 1-16. https://doi.org/10.1037/a0017634

Halbesleben, J. R. B., Wakefield, D. S., \& Wakefield, B. J. (2008). Work-arounds in health care settings. Health Care Management Review, 33(1), 2-12. https://doi.org/10.1097/01.hmr.0000304495.95522.ca

Halbesleben, J. R. B., Wheeler, A. R., \& Paustian-Underdahl, S. C. (2013). The impact of furloughs on emotional exhaustion, self-rated performance, and recovery experiences. Journal of Applied Psychology, 98(3), 492-503. https://doi.org/10.1037/a0032242

Hall, G. B., Dollard, M. F., \& Coward, J. (2010). Psychosocial safety climate: Development of the PSC-12. International Journal of Stress Management, 17(4), 353-383. https://doi.org/10.1037/a0021320

Lai, J., Ma, S., Wang, Y., Cai, Z., Hu, J., Wei, N., Wu, J., Du, H., Chen, T., Li, R., Tan, H., Kang, L., Yao, L., Huang, M., Wang, H., Wang, G., Liu, Z., \& Hu, S. (2020). Factors Associated with Mental Health Outcomes Among Health Care Workers Exposed to Coronavirus Disease 2019. JAMA Network Open, 3(3), e203976. https://doi.org/10.1001/jamanetworkopen.2020.3976

Luthans, F., \& Peterson, S. J. (2002). Employee engagement and manager self-efficacy. Journal of Management Development, 21(5), 376-387. https://doi.org/10.1108/02621710210426864

Makary, M. A., \& Daniel, M. (2016). Medical error - the third leading cause of death in the US. BMJ, i2139. https://doi.org/10.1136/bmj.i2139

MacLeod, D., \&amp; Clarke, N. (2009). Engaging for success: Enhancing performance through employee engagement: A report to government. PsycEXTRA Dataset. https://doi.org/10.1037/e576512011-001

Mansour, S., \& Commeiras, N. (2015). Le conflit travail-famille médiatise-t-il les effets des conditions de travail sur le stress professionnel ? Une étude auprès du personnel en contact dans le secteur hôtelier. Revue de Gestion Des Ressources Humaines, 95(1), 3. https://doi.org/10.3917/grhu.095.0003

Mansour, S., \& Tremblay, D. G. (2016). Work-family conflict/family-work conflict, job stress, burnout and intention to leave in the hotel industry in Quebec (Canada): moderating role of need for family friendly practices as "resource passageways." The International Journal of Human Resource Management, 29(16), 2399-2430. https://doi.org/10.1080/09585192.2016.1239216 
Mbambe, I. O., \& Maniam, R. (2018). Nurse-Patient Communication Barriers As Perceived By Adult In-Patients and Nurses in a Private Hospital in Malaysia. Volume-10: Issue 1, July, 2018, 10(1), 71-76. https://doi.org/10.31674/mjn.2018.v10i01.010

Mohd Rasdi, R., Zaremohzzabieh, Z., \& Ahrari, S. (2021). Financial Insecurity during the COVID-19 Pandemic: Spillover Effects on Burnout-Disengagement Relationships and Performance of Employees Who Moonlight. Frontiers in Psychology, 12, 1-14. https://doi.org/10.3389/fpsyg.2021.610138

Othman, N., \& Nasurdin, A. M. (2012). Social support and work engagement: a study of Malaysian nurses. Journal of Nursing Management, 21(8), 1083-1090. https://doi.org/10.1111/j.1365-2834.2012.01448.x

Permarupan, P. Y., al Mamun, A., Samy, N. K., Saufi, R. A., \& Hayat, N. (2020). Predicting Nurses Burnout through Quality of Work Life and Psychological Empowerment: A Study Towards Sustainable Healthcare Services in Malaysia. Sustainability, 12(1), 388. https://doi.org/10.3390/su12010388

Profit, J., Sharek, P. J., Amspoker, A. B., Kowalkowski, M. A., Nisbet, C. C., Thomas, E. J., Chadwick, W. A., \& Sexton, J. B. (2014). Burnout in the NICU setting and its relation to safety culture. BMJ Quality \& Safety, 23(10), 806-813. https://doi.org/10.1136/bmjqs-2014-002831

Rao, D.V., 2012. Nurse engagement in the Indian healthcare industry. Asian Journal of Research in Social Science \& Humanities,2(6): 139-145. View at Google Scholar

Ruotsalainen, J. H., Verbeek, J. H., Mariné, A., \& Serra, C. (2015). Preventing occupational stress in healthcare workers. Cochrane Database of Systematic Reviews. Published. https://doi.org/10.1002/14651858.cd002892.pub5

Saks, A. M. (2006). Antecedents and consequences of employee engagement. Journal of Managerial Psychology, 21(7), 600-619. https://doi.org/10.1108/02683940610690169

Salem, P. (2008). The seven communication reasons organizations do not change. Corporate Communications: An International Journal, 13(3), 333-348. https://doi.org/10.1108/13563280810893698

Schaufeli, W., \& Bakker, A. (2003). Utrecht work engagement scale: Preliminary manual. Utrecht: Occupational Health Psychology Unit, Utrecht University.

Seaman, J. B., \& Erlen, J. A. (2015). Workarounds in the Workplace. Orthopaedic Nursing, 34(4), 235-240. https://doi.org/10.1097/nor.0000000000000161

Sekaran, U., \& Bougie, R. (2019). Research Methods For Business: A Skill Building Approach (8th ed.). Wiley.

Serranheira, F. (2017, January 12). Ergonomia hospitalar e segurança do doente: mais convergências que divergências. Universidade Nova de Lisboa, Escola Nacional de Saúde Pública. https://run.unl.pt/handle/10362/19758 
Sheatsley, P. B. (1983). Questionnaire Construction and Item Writing. Handbook of Survey Research, 195-230. https://doi.org/10.1016/b978-0-12-598226-9.50012-4

Straub, D., \& Gefen, D. (2004). Validation Guidelines for IS Positivist Research. Communications of the Association for Information Systems, 13. https://doi.org/10.17705/1cais.01324

Sudman, S. (1983). Applied Sampling. Handbook of Survey Research, 145-194. https://doi.org/10.1016/b978-0-12-598226-9.50011-2

Tay, L. H., Ang, E., \& Hegney, D. (2012). Nurses' perceptions of the barriers in effective communication with inpatient cancer adults in Singapore. Journal of Clinical Nursing, 21(17-18), 2647-2658. https://doi.org/10.1111/j.1365-2702.2011.03977.x

Thomas, E. (2005a). Book Review To Do No Harm: Ensuring Patient Safety in Health Care Organizations By Julianne M. Morath and Joanne E. Turnbull. 354 pp. San Francisco, Jossey-Bass, 2005. \$42. 0-7879-6770-X. New England Journal of Medicine, 352(26), 2762-2763. https://doi.org/10.1056/nejm200506303522625

Thomas, E. (2005b). Book Review To Do No Harm: Ensuring Patient Safety in Health Care Organizations By Julianne M. Morath and Joanne E. Turnbull. 354 pp. San Francisco, Jossey-Bass, 2005. \$42. 0-7879-6770-X. New England Journal of Medicine, 352(26), 2762-2763. https://doi.org/10.1056/nejm200506303522625

United States of America - Report finds most errors at hospitals go unreported. (2012). International Journal of Health Care Quality Assurance, 25(4). https://doi.org/10.1108/ijhcqa.2012.06225daa.004

van Bogaert, P., Timmermans, O., Weeks, S. M., van Heusden, D., Wouters, K., \& Franck, E. (2014). Nursing unit teams' matter: Impact of unit-level nurse practice environment, nurse work characteristics, and burnout on nurse reported job outcomes, and quality of care, and patient adverse events-A cross-sectional survey. International Journal of Nursing Studies, 51(8), 1123-1134. https://doi.org/10.1016/j.ijnurstu.2013.12.009

Waymer, D., \& Ni, L. (2009). Connecting Organizations and their Employee Publics: The Rhetorical Analysis of Employee-Organization Relationships (EOR). In Heath, R.L., Toth, E. L., Waymer, D. (Eds). Rhetorical and Critical Approaches to Public Relations II. Abingdon: Routledge.

\section{Copyright Disclaimer}

Copyright for this article is retained by the author(s), with first publication rights granted to the journal.

This is an open-access article distributed under the terms and conditions of the Creative Commons Attribution license (http://creativecommons.org/licenses/by/4.0/). 